\title{
An acoustic and morphometric evaluation of the geographic distribution of Phyllomedusa burmeisteri (Anura: Phyllomedusidae), with comments on P. bahiana
}

\author{
Felipe Silva de Andrade, ${ }^{1,2,3}$ Isabelle Aquemi Haga, ${ }^{1}$ Thiago Ribeiro de Carvalho, ${ }^{4}$ Lucas Borges \\ Martins, ${ }^{1}$ and Ariovaldo Antonio Giaretta ${ }^{1}$ \\ ${ }^{1}$ Laboratório de Taxonomia e Sistemática de Anuros Neotropicais, Faculdade de Ciências Integradas do Pontal, Universidade \\ Federal de Uberlândia, Ituiutaba, MG, Brazil. E-mail: felipe_andrade@ymail.com. \\ ${ }^{2}$ Laboratório de História Natural de Anfíbios Brasileiros, Departamento de Biologia Animal, Instituto de Biologia, Universidade \\ Estadual de Campinas, Campinas, SP, Braz il. \\ ${ }^{3}$ Programa de Pós-Graduação em Biologia Animal, Instituto de Biologia, Universidade Estadual de Campinas, Campinas, SP, \\ Brazil. \\ ${ }^{4}$ Laboratório de Herpetologia, Departamento de Zoologia e Centro de Aquicultura, Instituto de Biociências, Universidade \\ Estadual Paulista, Rio Claro, SP, Brazil.
}

\begin{abstract}
An acoustic and morphometric evaluation of the geographic distribution of Phyllomedusa burmeisteri (Anura: Phyllomedusidae), with comments on P. bahiana. A recent study, based on phylogenetic and phylogeographic multilocus approaches, detected two evolutionary units (BUR and BUR-RJ) within the range of $P$. burmeisteri. BUR has a wide distribution, whereas BUR-RJ is restricted to a small area coincident with the Serra do Mar mountain range in the Brazilian state of Rio de Janeiro. We evaluate if acoustic and morphometric data support these two major clades within P. burmeisteri that were proposed using molecular evidence. We also provide for the first time detailed morphometric data for adult males of $P$. burmeisteri (including topotypes) and the holotype of $P$. bahiana, and we revisit the comparative acoustic diagnosis between $P$. burmeisteri and $P$. bahiana. We were unable to distinguish BUR and BUR-RJ evolutionary units based on morphometric, acoustic or any other feature of external morphology or coloration. Given the high levels of similarity in morphometric and acoustic traits between $P$. burmeisteri and P. bahiana, these features appear not to be informative in the differentiation of the two sister species.
\end{abstract}

Keywords: amphibians, bioacoustics, Leaf Frogs, taxonomy.

Received 19 February 2018

Accepted 15 May 2018

Distributed June 2018 


\begin{abstract}
Resumo
Uma avaliação acústica e morfométrica da distribuição geográfica de Phyllomedusa burmeisteri (Anura: Phyllomedusidae), com comentários sobre P. bahiana. Um estudo recente, baseado em abordagens filogenéticas e filogeográficas a partir de genes mitocondriais e nucleares, detectou duas unidades evolutivas (BUR e BUR-RJ) dentro da distribuição geográfica conhecida de P. burmeisteri. O estudo apontou que a linhagem BUR apresenta ampla distribuição, enquanto a BUR-RJ está restrita a uma pequena área coincidente com a Serra do Mar no estado do Rio de Janeiro. Neste estudo, nós avaliamos se os dados acústicos e morfométricos suportam esses dois clados de $P$. burmeisteri propostos com base em evidências moleculares. Também fornecemos dados morfométricos detalhados inéditos de machos adultos de P. burmeisteri (incluindo os topótipos), bem como do holótipo de $P$. bahiana. Além disso, revisitamos a diagnose acústica comparativa entre $P$. burmeisteri e $P$. bahiana proposta anteriormente na literatura. Não foi possível distinguir as unidades evolutivas (BUR e BUR-RJ) de $P$. burmeisteri com base em morfometria, bioacústica ou qualquer outro caráter da morfologia externa ou da coloração dos espécimes amostrados. Do mesmo modo, os caracteres morfométricos e acústicos parecem não ser informativos na diagnose comparativa entre $P$. burmeisteri e P. bahiana, uma vez que encontramos aqui altos níveis de similaridade entre essas duas espécies-irmãs.
\end{abstract}

Palavras-chave: anfíbios, bioacústica, pererecas-folha, taxonomia.

\section{Introduction}

The genus Phyllomedusa Wagler, 1830 comprises 16 species that occur from Panama to the Pacific slopes of Colombia, and South America east of the Andes, including Trinidad, southward to northern Argentina and Uruguay (Duellman et al. 2016, Frost 2018). Faivovich et al. (2010) found support for a clade within Phyllomedusa, the P. burmeisteri species group, which currently includes $P$. burmeisteri Boulenger, 1882, P. iheringii Boulenger, 1885, P. bahiana A. Lutz, 1925, P. distincta B. Lutz, 1950, and $P$. tetraploidea Pombal and Haddad, 1992 (Pombal and Haddad 1992, Brunes et al. 2010, Duellman et al. 2016).

Phyllomedusa burmeisteri was described based on syntypes from "Rio de Janeiro", "Brazil", and "Oran Salta, Buenos Ayres" (Boulenger 1882). Funkhouser (1957) suggested "Tijuca", municipality of Rio de Janeiro, state of Rio de Janeiro, as the type locality of this species, and that the specimen from Buenos Aires, Argentina is P. sauvagii Boulenger, 1882. Phyllomedusa burmeisteri is associated with lentic water bodies around clearings and forest borders throughout the Brazilian states of Bahia, Espírito Santo, Minas Gerais, Rio de Janeiro, and São Paulo (Pombal and Haddad 1992, Brunes et al. 2010, 2014). The advertisement call of the species was described based on two males from the municipality of Saquarema (RJ) (Abrunhosa and Wogel 2004). This species is acoustically distinguished from its sister species, $P$. bahiana, by distinct arrangements of the pulses along the call (presence of triads in $P$. bahiana), and tadpole morphology (Cruz 1982, Silva-Filho and Juncá 2006), as well as by molecular information (Brunes et al. 2010, 2014).

Based on phylogenetic and phylogeographic multilocus approaches Brunes et al. (2014) detected two evolutionary units (BUR and BUR$\mathrm{RJ})$ within the range of $P$. burmeisteri. According to this study, BUR is widely distributed, occurring in four Brazilian states: Espírito Santo, Minas Gerais, Rio de Janeiro, and São Paulo, whereas BUR-RJ is restricted to a small area within the Serra do Mar mountain range in the state of Rio de Janeiro. The range of BUR-RJ is partly delimited by the Paraíba do Sul River. The BUR 
lineage was also highly supported as an unconfirmed species by Brunes et al. (2014).

Here we evaluate whether phenotypic information supports the two major clades within P. burmeisteri proposed by Brunes et al. (2014), based on morphometric and/or acoustic data for 33 localities from four Brazilian states. We present detailed morphometric data for adult males of $P$. burmeisteri (including topotypes) and the holotype of $P$. bahiana. In addition, we revisit the comparative acoustic diagnosis between $P$. burmeisteri and $P$. bahiana proposed by Silva-Filho and Juncá (2006).

\section{Materials and Methods}

\section{Morphometry}

We collected the specimens under permit \#30059 issued by SISBio / ICMBio. Individuals were euthanized by applying 5\% lidocaine on their skin. We fixed specimens in $10 \%$ formalin and transferred them to $70 \%$ ethanol for permanent storage. These specimens are deposited in the collection of frogs at the Museu de Biodiversidade do Cerrado (AAG-UFU), Universidade Federal de Uberlândia, Uberlândia, Minas Gerais state, Brazil. We also analyzed specimens deposited in the following Brazilian collections: Adolpho Lutz Collection (AL-MN), housed in Museu Nacional, Rio de Janeiro, Rio de Janeiro state; amphibian collection of the Museu de Zoologia da Universidade Estadual de Campinas “Adão José Cardoso" (ZUEC), Universidade Estadual de Campinas, Campinas, São Paulo state; Célio F. B. Haddad Collection (CFBH), Universidade Estadual Paulista (UNESP), Rio Claro, São Paulo state; and Museu Nacional (MNRJ), Rio de Janeiro, Rio de Janeiro state.

Morphometric features were measured using Mitutoyo digitimatic calipers CD-6" CSX to the nearest $0.1 \mathrm{~mm}$. Eleven traits were measured following Watters et al. (2016): snout-vent length (SVL), thigh length (THL), foot length (FL), head length (HL), head width (HW), eye diameter (ED), tibia length (TL) (= shank length), tympanum diameter (TD), eye-nostril distance (END), and disc diameters of third finger (3FD) and fourth toe (4TD).

The morphometric data for adult males of $P$. burmeisteri were classified according to the two evolutionary units proposed by Brunes et al. (2014): BUR and BUR-RJ. The municipalities classified as BUR were: Alpinópolis, Carangola, Chiador, Conceição do Mato Dentro (Serra do Cipó), Juiz de Fora, Matutina, São José da Barra, and Viçosa (all in Minas Gerais state); Linhares (Espírito Santo state); Atibaia, Campinas, Corumbataí, Itatiba, Jundiaí, Nazaré Paulista, Rio Claro, and Santo André (all in São Paulo state). Of the 33 males measured from BUR, 10 are molecular vouchers in the genetic analysis by Brunes et al. (2014). The municipalities classified as BUR-RJ were: Cachoeiras de Macacu, Campos dos Goytacazes, Duque de Caxias, Macaé, Santa Maria Madalena, Nova Iguaçu, Engenheiro Paulo de Frontin, Rio de Janeiro, Petrópolis, São Gonçalo, and São Pedro da Aldeia (all in state of Rio de Janeiro). Of the 38 males measured from BUR-RJ, 11 are molecular vouchers in the genetic analysis by Brunes et al. (2014). Three specimens are topotypes from "Tijuca", Rio de Janeiro, and three other specimens are from other localities near the type locality within the municipality of Rio de Janeiro (RJ). Additionally, we also measured four adult females of BUR-RJ.

We measured the holotype of $P$. bahiana (AL-MNRJ 768). For comparison, we measured 24 adult males of $P$. bahiana: nine from Alagoinhas, two from Gandu, three from Ilhéus, two from Itagibá, two from Jequié, three from Maracás, and three from Piatã (Chapada Diamantina); all these municipalities are in the state of Bahia (Figure 1). Further details on all specimens are given in Appendix I.

\section{Bioacoustics}

In the field, we recorded calls with the digital recorders Marantz PMD 670, Marantz PMD 671, Boss 864 (all three with Sennheiser ME67/ 

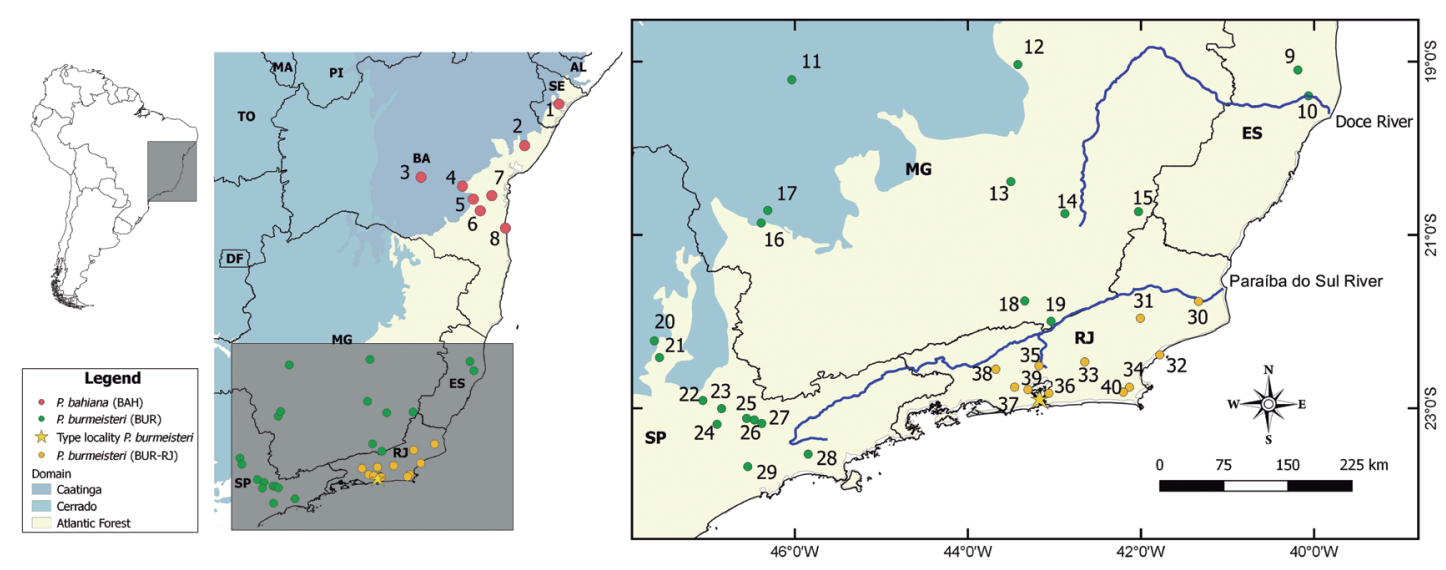

Figure 1. Map of the eastern portion of Brazil showing Brazilian domains and samples included in our morphometric and acoustic analyses. The type locality of Phyllomedusa burmeisteri is indicated with a yellow star. The inset shows in detail the sampled localities for the two evolutionary units of $P$. burmeisteri (BUR and BURRJ) proposed by Brunes et al. (2014). Municipalities: P. bahiana: (1) Areia Branca; (2) Alagoinhas; (3) Piatã; (4) Maracás; (5) Jequié; (6) Itagibá; (7) Gandu; (8) Ilhéus; (9) Sooretama; (10) Linhares; (11) Matutina; (12) Conceição do Mato Dentro; (13) Ouro Preto; (14) Viçosa; (15) Carangola; (16) Alpinópolis; (17) São José da Barra; (18) Juiz de Fora; (19) Chiador; (20) Corumbataí; (21) Rio Claro; (22) Campinas; (23) Itatiba; (24) Jundiaí; (25) Atibaia; (26) Bom Jesus dos Perdões; (27) Nazaré Paulista; (28) Salesópolis; (29) Santo André; (30) Campos dos Goytacazes; (31) Santa Maria Madalena; (32) Macaé; (33) Cachoeiras de Macacu; (34) São Pedro da Aldeia; (35) Petrópolis; (36) São Gonçalo; (37) Nova Iguaçu; (38) Engenheiro Paulo de Frontin; (39) Duque de Caxias; (40) Iguaba Grande. Brazilian states: Alagoas = AL; Bahia = BA; Espírito Santo = ES; Minas Gerais = MG; Rio de Janeiro = RJ; São Paulo = SP; Sergipe $=$ SE.

K6 directional microphone), Marantz PMD 661MKII, and M-audio Microtrack II (both with Sennheiser ME66/K6 directional microphones); sampling rates were 44.1 or $48.0 \mathrm{kHz}$ with a resolution of 16 bits. Acoustic terminology follows Köhler et al. (2017). The presence (state " 0 ") or absence (state " 1 ") of pulse groups along the call was evaluated for each male recorded. We calculated grand means and standard deviations from mean values for each male recorded, whereas the range (variation) encompassed the absolute minimum and maximum values among the samples. Air temperature was measured using a handheld digital thermometer to the nearest $0.1^{\circ} \mathrm{C}$. Calls were analyzed using Raven Pro 1.5, 64-bit version (Bioacoustics Research Program 2014) with the following settings: window type $=$ Hann, window size $=256$ samples, $3 \mathrm{~dB}$ filter bandwidth $=248$ or $270 \mathrm{~Hz}$, brightness =
$50 \%$, contrast $=50 \%$, overlap $=85 \%$ (locked), DFT size $=1024$ samples (locked), grid spacing $($ spectral resolution $)=43.1$ or $46.9 \mathrm{~Hz}$, color map $=$ Cool. Temporal traits were measured in the oscillogram and spectral traits were measured in the spectrogram. Raven Pro 1.5 obtained the dominant frequency and other frequency bands automatically through the "Peak Frequency $(\mathrm{Hz})$ " measurement function by the manual selection of call units. The values of the dominant frequency trait refer to the peak reached in the call. We generated call figures using the package 'seewave' version 2.0.5 (Sueur et al. 2008) in R version 3.4.1 ( $\mathrm{R}$ Core Team 2017). Seewave settings were Hanning window, $90 \%$ overlap and 512 points resolution (FFT).

We recorded and analyzed calls from 35 adult males of $P$. burmeisteri, which were also classified according to the two evolutionary units 
proposed by Brunes et al. (2014). Thirty-one males of the following municipalities were classified as BUR: Alpinópolis, Chiador, and Ouro Preto (state of Minas Gerais); Atibaia, Bom Jesus dos Perdões, Campinas, Itatiba, and Salesópolis (state of São Paulo); and Sooretama (state of Espírito Santo). Four males from municipality of Macaé (state of Rio de Janeiro) were classified as BUR-RJ. For acoustic comparisons between $P$. burmeisteri and $P$. bahiana, we recorded and analyzed six adult males of $P$. bahiana from the municipalities of Piatã and Ilhéus (state of Bahia), and Areia Branca (state of Sergipe).

Sound files were deposited in the Arquivo Sonoro da Coleção de Anuros da Universidade Federal de Uberlândia, Uberlândia (state of Minas Gerais), Brazil. Voucher specimens for call recordings of $P$. burmeisteri are: Macaé (state of Rio de Janeiro): AAG-UFU 0530 0531, 0751; Atibaia: AAG-UFU 0444, 0949; Campinas: AAG-UFU 1886-1888 (both in the state of São Paulo); Alpinópolis: AAG-UFU 0958, 4860-4862; Chiador: AAG-UFU 0678 (both in the state of Minas Gerais); Sooretama (state of Espírito Santo): AAG-UFU 6210, 6212. Voucher specimens of $P$. bahiana are: Ilhéus: AAG-UFU 0228; Piatã: AAG-UFU 1677-1679 (both in the state of Bahia) (Figure 2 ). Further details of the analyzed sound files are in Appendix II.

\section{Statistical Analysis}

The multivariate normality assumption was verified through the "mardiaTest" function in $\mathrm{R}$ (package 'MVN' version 4.0.2; Korkmaz et al. 2014), and it was applied to both the morphometric and acoustic data (results $=$ data are not multivariate normal). Considering the (multivariate) acoustic and morphometric data, we searched for discrimination among the two evolutionary units of $P$. burmeisteri (BUR and BUR-RJ) and $P$. bahiana by applying the Random Forests (RF) model (Breiman 2001) using the package 'randomForest' version 4.6-12 in R (further details in Liaw and Wiener 2002). The RF results include an estimate of distances among the objects and a Multidimensional Scaling Analysis (MDS). This analisys can be plotted with the "proximityPlot" function of the package 'rfPermute' version 2.1.5 (Archer 2016), which also allows the results to be displayed graphically. Analyses were conducted in $\mathrm{R}$.

For the multivariate, multidimensional analysis/plots and statistical tests, we used all the morphometric variables detailed earlier and the following acoustic traits: call duration; number of pulses per call; pulse duration; interpulse interval; pulses per second; presence or absence of pulse groups; and dominant frequency. Acoustic and morphometric traits indicated as important in the multivariate analysis were then tested for statistical significance of differences among the evolutionary units of $P$. burmeisteri and $P$. bahiana using the Exact Wilcoxon MannWhitney Rank Sum Test, function wilcox_test of the package 'coin' version 1.2-0 (Resampling Statistics model; Hothorn et al. 2008) in R. Significance was considered when $p<0.05$. The significance levels (" $p$ ") of the pairwise comparisons were adjusted considering the number of pairings using the method of Holm (p.adust function in $\mathrm{R}$ ).

\section{Results}

\section{Morphometry}

Morphometric features of $P$. burmeisteri (BUR and BUR-RJ) are summarized in Table 1. The adult male SVL of BUR ranged from 53-70 $\mathrm{mm}$ and that of BUR-RJ ranged from 54-69 mm. Overlap occurred between the other morphometric features (Table 1). The RandomForest multivariate approach applied to morphometric data indicated a broad overlap among all three partitions (Figure 3A). We found no statistical significance in any trait.

Measurements of the holotype of P. bahiana (AL-MN 768, collected in February 1924 in 

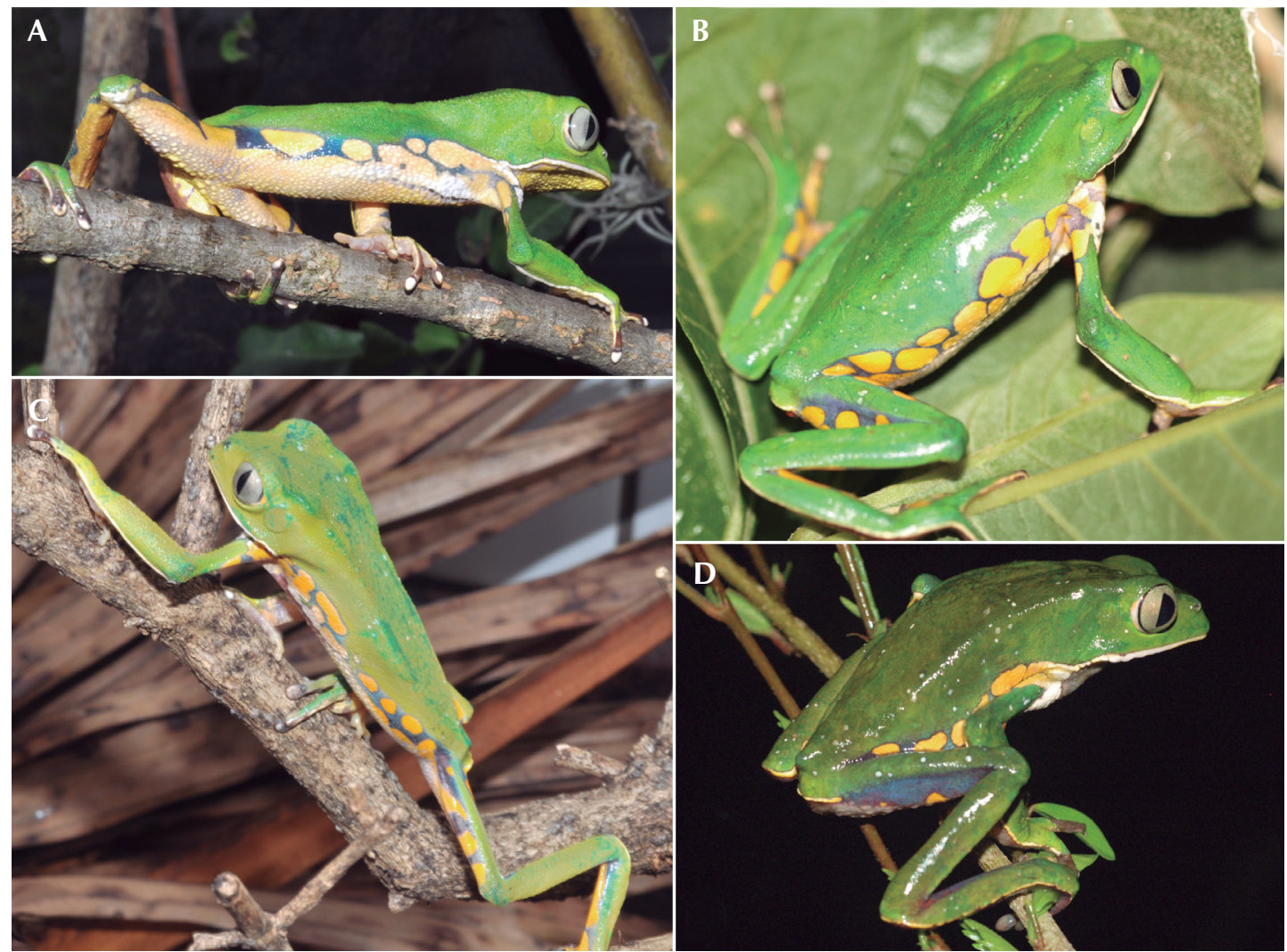

Figure 2. Adult males of Phyllomedusa burmeisteri in life from Brazilian municipalities of Atibaia (A), state of São Paulo (AAG-UFU 0958); Macaé (B), state of Rio de Janeiro (AAG-UFU 0530); and Alpinópolis (C), state of Minas Gerais (AAG-UFU 4860); and an adult male of $P$. bahiana from municipality of Ilhéus (D), state of Bahia (AAG-UFU 0229). All these males are call vouchers.

Salvador, state of Bahia) are in Table 1. The holotype is currently somewhat fragile; the head is slightly arched ventrally; a cross section is present on the skin of the chest; the mouth is open, with tongue visible and has a brownferruginous faded coloration.

\section{Advertisement Call of $\mathrm{P}$. burmeisteri-BUR and BUR-RJ Evolutionary Units}

The advertisement call of $P$. burmeisteri (BUR-RJ) consisted of a multi-pulsed note emitted sporadically (Figure 4A, B), lasting
186-409 ms, separated by intervals of 6-44 s. Calls had 9-15 pulses arranged in 4-6 pulse groups per call, containing 2-5 pulses per group (Figure 4A), or regularly spaced $(N=1$ male, Figure 4B). When present, pulse groups lasted 23-122 ms, separated by intervals of 10-41 ms. The pulse duration varied from 2-15 ms, separated by intervals of 2-35 ms. Pulses were released at a rate of 37-53 pulses per second. The dominant frequency (= fundamental) varied from 1031-1219 Hz.

The advertisement call of $P$. burmeisteri (BUR) also consisted of a multi-pulsed note 
BAH BUR BUR-RJ
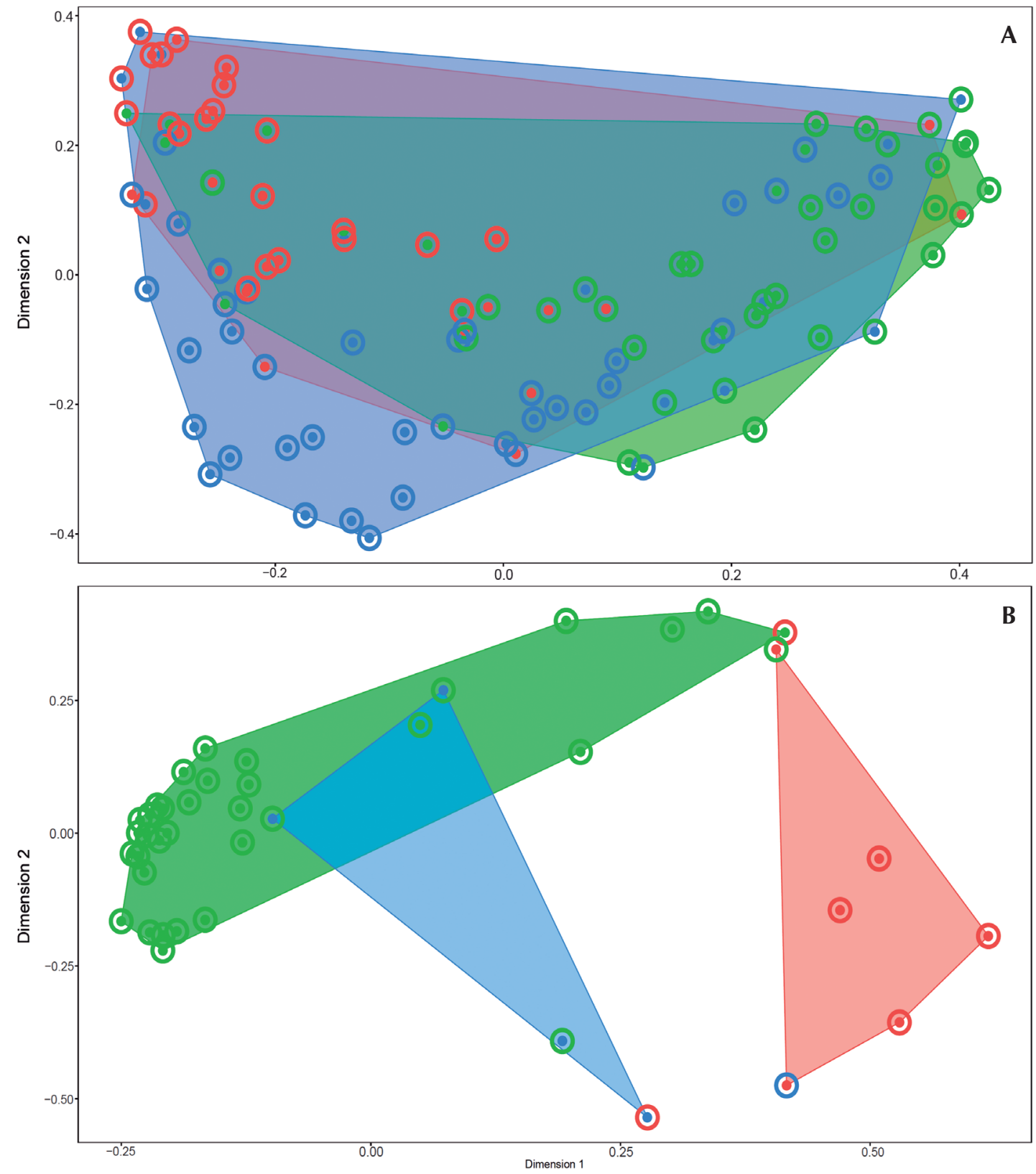

Figure 3. First and second dimensions of the Multidimensional scaling on the proximity scores from the Random Forest analysis considering morphometric (A) and acoustic (B) traits of adult males belonging to the BUR (green dots) and BUR-RJ (blue dots) evolutionary units of P. burmeisteri (according to Brunes et al. 2014), and adult males of $P$. bahiana (red dots). 
Table 1. Morphometry of adult specimens of the two evolutionary units of Phyllomedusa burmeisteri (BUR and BURRJ) (according to Brunes et al. 2014) from 27 municipalities of four Brazilian states, and holotype and adult males of $P$. bahiana from seven municipalities of the state of Bahia. Values in $\mathrm{mm}$ as mean $\pm \mathrm{SD}$ (minimummaximum). $N=$ number of measured specimens. See Appendix $I$.

\begin{tabular}{|c|c|c|c|c|c|}
\hline \multirow[b]{2}{*}{ Traits } & \multirow{2}{*}{$\begin{array}{c}\text { P. burmeisteri } \\
\text { (BUR) }\end{array}$} & \multicolumn{2}{|c|}{$\begin{array}{l}\text { P. burmeisteri } \\
\text { (BUR-RJ) }\end{array}$} & \multicolumn{2}{|c|}{ P. bahiana } \\
\hline & & $\begin{array}{c}\text { Males } \\
(N=38)\end{array}$ & $\begin{array}{c}\text { Females } \\
(N=4)\end{array}$ & $\begin{array}{l}\text { Holotype } \\
\text { "unsexed" }\end{array}$ & $\begin{array}{c}\text { Males } \\
(N=25)\end{array}$ \\
\hline Snout-vent length & $\begin{array}{c}61.5 \pm 4.0 \\
(52.7-70.4)\end{array}$ & $\begin{array}{c}62.4 \pm 3.6 \\
(53.8-69.2)\end{array}$ & $\begin{array}{c}74.8 \pm 5.6 \\
(69.0-81.6)\end{array}$ & 70.4 & $\begin{array}{c}65.8 \pm 4.0 \\
(56.4-73.9)\end{array}$ \\
\hline Head length & $\begin{array}{c}14.8 \pm 1.3 \\
(12.2-17.5)\end{array}$ & $\begin{array}{c}14.7 \pm 1.4 \\
(12.0-19.2)\end{array}$ & $\begin{array}{c}16.3 \pm 0.7 \\
(15.9-17.4)\end{array}$ & 12.7 & $\begin{array}{c}15.8 \pm 1.5 \\
(12.7-18.3)\end{array}$ \\
\hline Head width & $\begin{array}{c}20.1 \pm 1.6 \\
(17.4-23.7)\end{array}$ & $\begin{array}{c}21.2 \pm 1.2 \\
(18.2-23.4)\end{array}$ & $\begin{array}{c}25.9 \pm 0.9 \\
(24.8-26.9)\end{array}$ & 23.0 & $\begin{array}{c}21.5 \pm 1.5 \\
(17.6-24.2)\end{array}$ \\
\hline Eye diameter & $\begin{array}{l}6.3 \pm 0.5 \\
(5.3-7.7)\end{array}$ & $\begin{array}{l}6.8 \pm 0.5 \\
(5.7-8.0)\end{array}$ & $\begin{array}{l}7.4 \pm 0.5 \\
(6.9-8.0)\end{array}$ & 6.6 & $\begin{array}{l}7.0 \pm 0.7 \\
(6.3-8.9)\end{array}$ \\
\hline Eye-nostril distance & $\begin{array}{l}5.3 \pm 0.4 \\
(4.4-6.1)\end{array}$ & $\begin{array}{l}5.4 \pm 0.3 \\
(4.8-6.2)\end{array}$ & $\begin{array}{l}6.3 \pm 0.3 \\
(6.0-6.5)\end{array}$ & 5.8 & $\begin{array}{l}5.5 \pm 0.5 \\
(4.5-6.3)\end{array}$ \\
\hline Tympanum diameter & $\begin{array}{l}3.7 \pm 0.4 \\
(3.0-4.5)\end{array}$ & $\begin{array}{l}3.5 \pm 0.4 \\
(2.2-4.5)\end{array}$ & $\begin{array}{l}4.1 \pm 0.5 \\
(3.4-4.5)\end{array}$ & 2.9 & $\begin{array}{l}4.0 \pm 0.5 \\
(2.9-5.1)\end{array}$ \\
\hline Thigh length & $\begin{array}{c}26.6 \pm 1.7 \\
(23.1-30.8)\end{array}$ & $\begin{array}{c}27.4 \pm 1.7 \\
(23.3-30.9)\end{array}$ & $\begin{array}{c}31.8 \pm 2.0 \\
(30.3-34.8)\end{array}$ & 26.9 & $\begin{array}{c}28.6 \pm 1.5 \\
(24.8-31.3)\end{array}$ \\
\hline Tibia length & $\begin{array}{c}26.1 \pm 1.9 \\
(22.6-30.6)\end{array}$ & $\begin{array}{c}27.2 \pm 1.7 \\
(23.9-30.9)\end{array}$ & $\begin{array}{c}32.5 \pm 2.3 \\
(30.5-35.3)\end{array}$ & 26.6 & $\begin{array}{c}27.6 \pm 1.7 \\
(22.7-29.8)\end{array}$ \\
\hline Foot length & $\begin{array}{c}21.8 \pm 1.7 \\
(18.9-26.5)\end{array}$ & $\begin{array}{c}22.4 \pm 1.5 \\
(18.3-25.1)\end{array}$ & $\begin{array}{c}26.8 \pm 2.1 \\
(25.0-29.9)\end{array}$ & 20.5 & $\begin{array}{c}22.1 \pm 1.7 \\
(18.3-24.7)\end{array}$ \\
\hline Third finger disc diameter & $\begin{array}{l}2.0 \pm 0.2 \\
(1.6-2.5)\end{array}$ & $\begin{array}{l}1.9 \pm 0.4 \\
(1.3-2.6)\end{array}$ & $\begin{array}{l}2.2 \pm 0.9 \\
(1.6-3.5)\end{array}$ & 1.1 & $\begin{array}{l}2.1 \pm 0.3 \\
(1.1-2.9)\end{array}$ \\
\hline Fourth toe disc diameter & $\begin{array}{l}2.0 \pm 0.2 \\
(1.6-2.5)\end{array}$ & $\begin{array}{l}1.9 \pm 0.4 \\
(1.1-2.8)\end{array}$ & $\begin{array}{l}2.1 \pm 0.9 \\
(1.4-3.5)\end{array}$ & 1.4 & $\begin{array}{l}2.1 \pm 0.3 \\
(1.4-2.9)\end{array}$ \\
\hline
\end{tabular}

emitted sporadically (Figure 4C), lasting 130$881 \mathrm{~ms}$, separated by intervals of 1-89 s. Calls had 7-31 regularly spaced pulses (pulse groups absent). The pulse duration varied from 2-22 ms, separated by intervals of 1-70 ms. Pulses were released at a rate of 26-67 pulses per second. The dominant frequency $(=$ fundamental) varied from 937-1636 Hz. All quantitative traits for both evolutionary units are summarized in Table 2.

\section{Acoustic Comparisons}

Regarding calls, the RandomForest multivariate approach revealed no discrimination between the three partitions (Table 3, Figure 


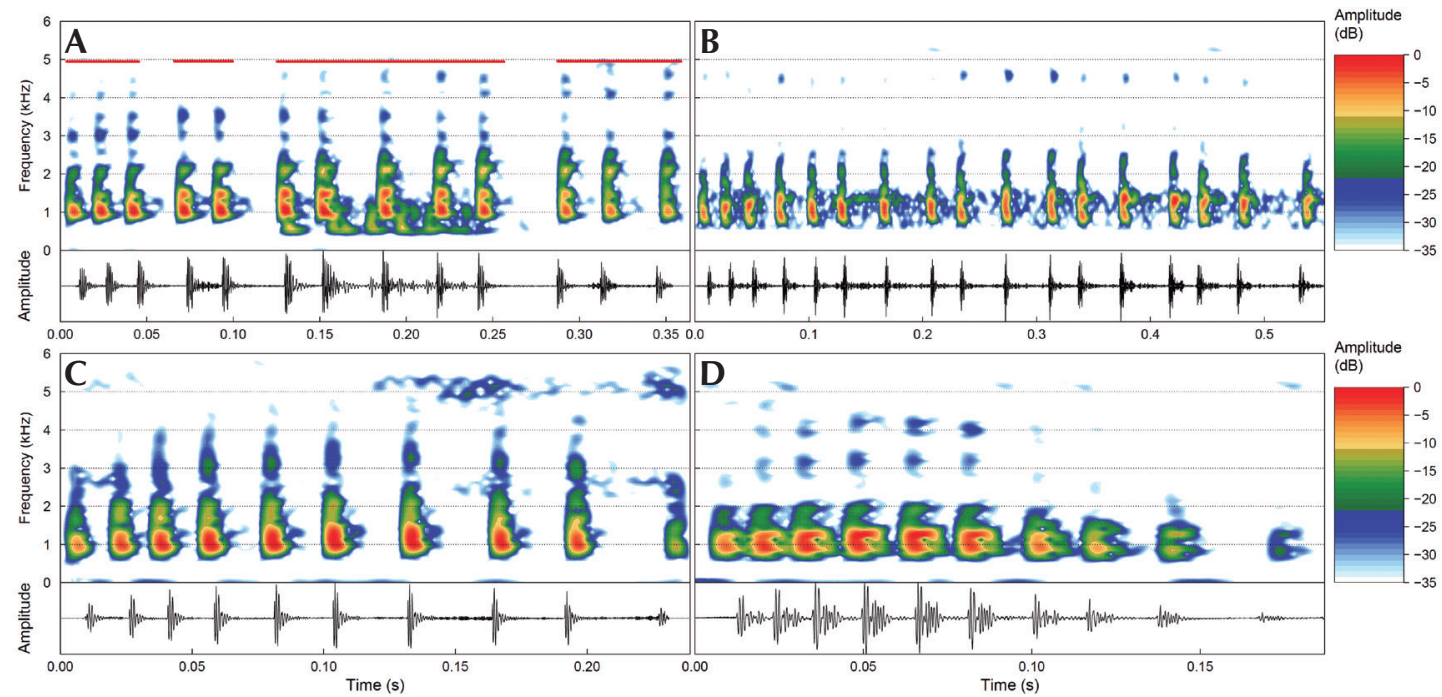

Figure 4. Audiospectogram (above) and corresponding oscillogram (below) of advertisement calls of Phyllomedusa burmeisteri (A-C) and P. bahiana (D). (A) Call with four pulse groups (red lines highlight them). (B) Call without pulse groups (pulses regularly spaced). These calls represent two males of $P$. burmeisteri (BUR-RJ) from Macaé, state of Rio de Janeiro. (C) Call of a male of $P$. burmeisteri (BUR) from Atibaia, state of São Paulo. (D) Call without pulse groups of a male of $P$. bahiana from Ilhéus, state of Bahia. Sound files: (A) Phyllom_burmeisMacaeRJ2bLBM_AAGmt; (B) Phyllom_burmeisMacaeRJ3cTRC_AAGmt; (C) Phyllom_ burmeistAtibaiaSP5aAAGm671; and (D) Phyllom_bahianalheusBA2aTRC_AAGmt. Further details of these analyzed sound files are in Appendix II.

3B). The values of all traits broadly overlapped (Table 2). The only noticeable difference was the presence of pulse groups (Figure 4A) in three males from Macaé (BUR-RJ). However, we analyzed a male from this same locality without these groups (Figure 4B), which emitted calls similar to those of males from the BUR lineage (Figure 4C).

The RandomForest analysis revealed no discrimination between males of $P$. bahiana and males from either lineages of $P$. burmeisteri (Table 3, Figure 3B). We found a significant difference between BUR and P. bahiana in the interpulse interval; however, considerable overlap occurred between these traits (Table 2). Five of the six males of $P$. bahiana analyzed emitted calls with pulses arranged in 2-7 groups, which had 3-6 pulses per group. One male from Ilhéus emitted calls without pulse groups, but with pulses regularly spaced (Figure 4D).

\section{Discussion}

\section{Is There Phenotypic Divergence Between the $B U R$ and BUR-RJ Evolutionary Units?}

Regarding morphometry, values of snoutvent length (SVL) for Phyllomedusa burmeisteri (both BUR and BUR-RJ) are scattered in the literature. Morphometric data on the holotype of $P$. bahiana is provided here for the first time. Pombal and Haddad (1992) provided SVL for $P$. burmeisteri, which ranged from 55.0 to $75.8 \mathrm{~mm}$ (mean $=61.9 \mathrm{~mm}, \mathrm{SD}=4.1, N=75)$, based on adult males from a broad area within the distribution of BUR and BUR-RJ. Abrunhosa and Wogel (2004) provided a mean SVL of 63.4 
Table 2. Advertisement call traits for the two evolutionary units of Phyllomedusa burmeisteri (BUR and BUR-RJ) (according to Brunes et al. 2014) from nine municipalities of three Brazilian states, and for P. bahiana from three municipalities of two Brazilian states. Mean \pm standard deviation (minimum-maximum). $N=$ number of males analyzed (number of calls analyzed).

\begin{tabular}{|c|c|c|c|}
\hline \multirow[b]{2}{*}{ Traits } & \multicolumn{2}{|c|}{ Phyllomedusa burmeisteri } & \multirow{2}{*}{$\begin{array}{c}\text { Phyllomedusa bahiana } \\
N=6(91)\end{array}$} \\
\hline & $\begin{array}{c}\text { BUR } \\
N=31(321)\end{array}$ & $\begin{array}{c}\text { BUR-RJ } \\
N=4(30)\end{array}$ & \\
\hline Call duration (s) & $\begin{array}{l}0.313 \pm 0.120 \\
(0.130-0.881)\end{array}$ & $\begin{array}{l}0.281 \pm 0.094 \\
(0.186-0.409)\end{array}$ & $\begin{array}{l}0.219 \pm 0.074 \\
(0.099-0.579)\end{array}$ \\
\hline Intercall interval (s) & $\begin{array}{l}13.6 \pm 8.7 \\
(1.4-88.9)\end{array}$ & $\begin{array}{l}13.3 \pm 5.6 \\
(6.1-44.5)\end{array}$ & $\begin{array}{l}15.9 \pm 9.9 \\
(1.0-58.5)\end{array}$ \\
\hline Number of pulses per call & $\begin{array}{l}13.1 \pm 3.7 \\
(7.0-31.0)\end{array}$ & $\begin{array}{l}11.8 \pm 2.3 \\
(9.0-15.0)\end{array}$ & $\begin{array}{l}10.7 \pm 2.5 \\
(6.0-19.0)\end{array}$ \\
\hline Pulse duration (s) & $\begin{array}{l}0.008 \pm 0.002 \\
(0.002-0.022)\end{array}$ & $\begin{array}{l}0.007 \pm 0.001 \\
(0.002-0.015)\end{array}$ & $\begin{array}{l}0.007 \pm 0.002 \\
(0.002-0.035)\end{array}$ \\
\hline Interpulse interval (s) & $\begin{array}{l}0.017 \pm 0.005 \\
(0.001-0.070)\end{array}$ & $\begin{array}{l}0.016 \pm 0.003 \\
(0.002-0.035)\end{array}$ & $\begin{array}{l}0.010 \pm 0.003 \\
(0.002-0.039)\end{array}$ \\
\hline Pulses per second & $\begin{array}{c}44.1 \pm 8.6 \\
(26.2-66.7)\end{array}$ & $\begin{array}{c}43.6 \pm 6.6 \\
(36.7-52.9)\end{array}$ & $\begin{array}{c}51.2 \pm 9.4 \\
(28.6-68.7)\end{array}$ \\
\hline Number of pulse groups per call & - & $\begin{array}{l}4.9 \pm 0.2 \\
(4.0-6.0)\end{array}$ & $\begin{array}{l}3.1 \pm 1.8 \\
(2.0-7.0)\end{array}$ \\
\hline Number of pulses per group & - & $2-5$ & $3-6$ \\
\hline Duration of pulse groups (s) & - & $\begin{array}{l}0.051 \pm 0.002 \\
(0.023-0.122)\end{array}$ & $\begin{array}{l}0.031 \pm 0.016 \\
(0.017-0.068)\end{array}$ \\
\hline Intergroup of pulses interval (s) & - & $\begin{array}{l}0.030 \pm 0.001 \\
(0.010-0.041)\end{array}$ & $\begin{array}{l}0.022 \pm 0.014 \\
(0.009-0.067)\end{array}$ \\
\hline Dominant frequency $(\mathrm{Hz})$ & $\begin{array}{l}1180.9 \pm 106.1 \\
(937.5-1636.5)\end{array}$ & $\begin{array}{c}1117.2 \pm 51.8 \\
(1031.2-1218.8)\end{array}$ & $\begin{array}{c}1128.8 \pm 65.1 \\
(937.0-1359.4)\end{array}$ \\
\hline Air temperature $\left({ }^{\circ} \mathrm{C}\right)$ & $16.0-25.5$ & $21.0-24.1$ & $23.0-25.0$ \\
\hline Water temperature $\left({ }^{\circ} \mathrm{C}\right)$ & $18.0-28.0$ & $22.0-30.3$ & $22.0-27.0$ \\
\hline
\end{tabular}

Table 3. Confusion matrix for the two evolutionary units (BUR and BUR-RJ) of Phyllomedusa burmeisteri and P. bahiana based on morphometric and acoustic (values in bold) datasets through a Random Forests model. Settings: number of tree permutations $=1000$; number of variables tried at each split $=3.0$ | 2.0; error rates $=40.62 \%$ | $\mathbf{1 7 . 0 7} \%$.

\begin{tabular}{lcccc}
\hline & $\begin{array}{c}\text { P. burmeisteri } \\
\text { (BUR) }\end{array}$ & $\begin{array}{c}\text { P. burmeisteri } \\
\text { (BUR-RJ) }\end{array}$ & P. bahiana & class.error \\
\hline P. burmeisteri (BUR) & $20 \mid \mathbf{3 0}$ & $7 \mid \mathbf{0}$ & $6 \mid \mathbf{1}$ & $0.39 \mid \mathbf{0 . 0 3}$ \\
P. burmeisteri (BUR-RJ) & $8 \mid \mathbf{3}$ & $25 \mid \mathbf{0}$ & $5 \mid \mathbf{1}$ & $0.34 \mid \mathbf{1 . 0 0}$ \\
P. bahiana & $6 \mid \mathbf{1}$ & $7 \mid \mathbf{1}$ & $12 \mid \mathbf{4}$ & $0.52 \mid \mathbf{0 . 3 3}$ \\
\hline
\end{tabular}


$\pm 4.5(N=13)$ for specimens from Saquarema (BUR-RJ). The SVL values of P. burmesiteri (BUR and BUR-RJ) provided here broadly overlap with the values of both studies cited above. The values of all other morphometric features of the two evolutionary units presented here overlapped, and the multivariate classification method (RandomForest) did not allow discrimination between either evolutionary units of $P$. burmeisteri, or between the two units and $P$. bahiana. Therefore, we were unable to distinguish BUR and BUR-RJ based on morphometric features or any other feature of external morphology or coloration, e.g., color of the hidden areas of the thighs, as already pointed out by Brunes et al. (2014).

Brunes et al. (2014) suggested that the taxonomic status of the novel evolutionary unit (BUR) would benefit from an integrative approach, including other sources of information, such as reproductive aspects related to prezygotic isolation. In addition, they noted that delimitation of the BUR evolutionary unit is not fully congruent across different types of markers and methods, presenting several challenges for the taxonomic significance of this novel evolutionary unit. We were also unable to distinguish BUR and BUR-RJ based on acoustic evidence. Indeed, further fine-scale studies to evaluate other sources of information for these two lineages, specifically cytogenetic and larval data, may shed further light on the possible differences between them.

Advertisement Call of Phyllomedusa burmeisteri

Abrunhosa and Wogel (2004) recognized two types of advertisement calls of $P$. burmeisteri, the short call (duration: $330-450 \mathrm{~ms}$ ) and the long call (duration: 560-600 ms). Abrunhosa and Wogel (2004) also reported that pulses tended to be arranged in groups of three and the first triads of the call were closer to one another than the others, independently of the number of pulses per call. These observations were based on two males, each one displaying only one type of call (short or long). Intermediate call duration was found in $10 \%$ of the calls of six males from BUR analyzed by us, with values that do not fit the values of minimum and maximum of the short or long calls in Abrunhosa and Wogel (2004). In addition, during our field recordings, we did not record long calls of males from BURRJ, as defined by Abrunhosa and Wogel (2004). We believe dividing the advertisement call of this species into these two categories as proposed by Abrunhosa and Wogel (2004) is unwarrarited until additional data on acoustic variation of the species are obtained.

Three males of BUR-RJ had pulse groups (2-5 pulses per group) in their calls, and another individual had regularly spaced pulses (no pulse groups), similar to all males of BUR. Pulse groups may have more than three pulses, as mentioned in Abrunhosa and Wogel (2004), and their presence is variable enough that this acoustic trait is not useful in determining taxonomy of these species or for differentiating the two evolutionary units of $P$. burmeisteri.

\section{Do P. burmeisteri and P. bahiana Differ Acoustically?}

Pombal and Haddad (1992) stated that $P$. burmeisteri and $P$. bahiana had advertisement calls composed of isolated and regularly spaced pulses. Later, Silva-Filho and Juncá (2006) distinguished the advertisement calls of $P$. bahiana and $P$. burmeisteri. They reported that $P$. bahiana had well-defined pulse triads (threepulse groups), whereas $P$. burmeisteri had an advertisement call formed by two types of calls, both having pulses tending to be arranged in triads, but spaced almost regularly (Abrunhosa and Wogel 2004) or pulses generally isolated and spaced regularly (Pombal and Haddad 1992). Additionally, Silva-Filho and Juncá (2006) found that the number of pulses and pulse rate of $P$. bahiana were, respectively, lower and higher than in P. burmeisteri, and the pulse duration of $P$. bahiana was half the duration of that of $P$. burmeisteri (Abrunhosa and Wogel 2004). 
As stated above, we did not identify the two types of calls reported by Abrunhosa and Wogel (2004) among the calls recorded by us for $P$. burmeisteri. Based on our larger sample, pulses in the calls of these two species are not only arranged in triads. Our results indicate that the pulse groups of $P$. burmeisteri (BUR and BUR$\mathrm{RJ})$ can be composed of 2 to 5 pulses, whereas they are composed of 3 to 6 pulses in $P$. bahiana. Thus, the term "triad" cannot be applied to all pulse groups, so we referred herein to all pulse group arrangements simply as pulse groups.

Besides being quite variable, the presence of pulse groups is clearly not a reliable diagnostic character for these two species. This trait was lacking in one male of P. bahiana from llhéus, and males of $P$. burmeisteri (BUR and BUR-RJ) had calls with (or without) groups of pulses. "Pulse groups" seems to be a more frequent trait in P. bahiana and BUR-RJ than it is in BUR. We were unable to distinguish $P$. bahiana and $P$. burmeisteri based on their number of pulses, pulse duration, and pulse rate, as previously suggested by Silva-Filho and Juncá (2006). We found overlap in all values of the acoustic traits presented here for these two species (Table 2). Therefore, no qualitative or quantitative acoustic trait can be used to distinguish $P$. burmeisteri from $P$. bahiana.

Silva-Filho and Juncá (2006) pointed out differences between these species in larval morphology and territorial calls. Future finescale studies are needed to better understand the relevance of these differences. The results of Brunes et al. (2014) may reflect a combination of distinct episodes of secondary contact between $P$. bahiana and P. burmeisteri, possibly an older hybridization event in the Espírito Santo region, and a more recent secondary contact in southern Bahia. Studies are needed to better understand whether effective reproductive barriers exist between these leaf frog species, because their advertisement calls do not seem to be a good prezygotic barrier of reproductive isolation.

It is well known that rivers serve as geographical barriers for terrestrial vertebrates such as reptiles, birds, and mammals (Wallace 1852, Gascon et al. 1996, Patton et al. 2000, Hayes and Sewlal 2004), and several case studies have dealt with the influence of rivers on the distribution and genetic structure for amphibians, a semiaquatic group (see Gascon et al. 1998, 2000, Lougheed et al. 1999, Gehring et al. 2012, Yuan et al. 2016). Future studies should examine the role of major rivers of the Brazilian east Atlantic basin in the evolutionary history of $P$. burmeisteri and $P$. bahiana. Plio-Pleistocene climatic oscillations induced sea level fluctuations along the Brazilian coast, contributing to changes in the coastal plains of rivers across time. These changes were likely responsible for recurrent episodes of isolation and secondary contact between populations (Dominguez 2009, Brunes et al. 2014).

\section{Acknowledgments}

Special thanks to REBIO Sooretama for providing facilities during our research at this reserve. Bernardo F. V. Teixeira kindly made available a call recording of $P$. burmeisteri. J. P. Pombal Jr. and C. F. B. Haddad permitted the inspection of specimens in their care at AL-MN and MNRJ, and CFBH collections, respectively. We thank J. P. Pombal Jr. and three other anonymous reviewers for discussions and comments on previous versions of the manuscript. Janalee Caldwell revised the accepted version of this manuscript. Fonoteca Neotropical Jacques Vielliard (FNJV) kindly made available recordings of $P$. bahiana from Areia Branca, state of Sergipe. The São Paulo Research Foundation (FAPESP) provided a PhD fellowship to FSA (Process \#2015/10728-7) and a postdoctoral fellowship to TRC (Process \#2017/08489-0). The Conselho Nacional de Desenvolvimento Científico e Tecnológico (CNPq) and Fundação de Amparo à Pesquisa de Minas Gerais (FAPEMIG) provided financial support to AAG (Process \#305261/2010-0) and an undergraduate research project fellowship to IAH (Process \#FAPEMIG2012-BIO01). A grant by CNPq was 
awarded to AAG. We thank The Cornell Lab of Ornithology (Bioacoustics Research Program) for providing free licenses of Raven Pro.

\section{References}

Abrunhosa, P. A. and H. Wogel. 2004. Breeding behavior of the leaf-frog Phyllomedusa burmeisteri (Anura: Hylidae). Amphibia-Reptilia 25: 125-135.

Archer, E. 2016. rfPermute: Estimate Permutation p-Values for Random Forest Importance Metrics (Computer software). R package Version 2.1.5. URL: https:// CRAN.R-project.org/package=rfPermute.

Bioacoustics Research Program. 2014. Raven Pro: Interactive Sound Analysis Software (Computer software). Version 1.5. The Cornell Lab of Ornithology, Ithaca, New York. URL: http://www.birds.cornell.edu/raven.

Boulenger, G. A. 1882. Catalogue of the Batrachia Salientia s. Ecaudata in the Collection of the British Museum. $2^{\text {nd }}$ Edition. London. Taylor and Francis. 503 pp.

Breiman, L. 2001. Random Forests. Machine Learning 45: $5-32$.

Brunes, T. O., F. Sequeira, C. F. B. Haddad, and J. Alexandrino. 2010. Gene and species trees of a Neotropical group of treefrogs: genetic diversification in the Brazilian Atlantic Forest and the origin of a polyploid species. Molecular Phylogenetics and Evolution 57: $1120-1133$.

Brunes, T. O., J. Alexandrino, D. Baêta, J. Zina, C. F. B. Haddad, and F. Sequeira. 2014. Species limits, phylogeographic and hybridization patterns in Neotropical leaf frogs (Phyllomedusinae). Zoologica Scripta 43: 586-604.

Cruz, C. A. G. 1982. Conceituação de grupos de espécies de Phyllomedusinae brasileiras com base em caracteres larvários (Amphibia, Anura Hylidae). Arquivos da Universidade Federal Rural do Rio de Janeiro 5: 147 171.

Dominguez, J. M. L. 2009. The coastal zone of Brazil. Pp. 17-51 in S. R. Dillenburg and P. A. Hesp (eds.), Geology and Geomorphology of Holocene Coastal Barriers of Brazil. Berlin. Springer.

Duellman, W. E., A. B. Marion, and S. B. Hedges. 2016. Phylogenetics, classification, and biogeography of the treefrogs (Amphibia: Anura: Arboranae). Zootaxa 4104: 001-109.

Faivovich, J., C. F. B. Haddad, D. Baêta, K. H. Jungferd, G. F. R. Álvares, R. A. Brandão, C. Sheilf, L. S. Barrientos, C. L. Barrio-Amorós, C. A. G. Cruz, and W. C. Wheeler.
2010. The phylogenetic relationships of the charismatic poster frogs, Phyllomedusinae (Anura, Hylidae). Cladistics 26: 227-261.

Frost, D. R. 2018. Amphibian Species of the World: an Online Reference. Version 6.0 (03 May 2018). Eletronic Database accessible at http://research.amnh.org/ herpetology/amphibia/index.html. American Museum of Natural History, New York (USA). Captured on 15 May 2018.

Funkhouser, A. 1957. A review of the neotropical tree frogs of the genus Phyllomedusa. Occasional Papers of the Natural History Museum of Stanford University 5: 1-90.

Gascon, C., S. C. Lougheed, and J. P. Bogart. 1996. Genetic and morphological variation in Vanzolinius discodactylus: a test of the river hypothesis of speciation. Biotropica 28: 376-387.

Gascon, C., S. C. Lougheed, and J. P. Bogart. 1998. Patterns of genetic population differentiation in four species of Amazonian frogs: a test of the riverine barrier hypothesis. Biotropica 30: 104-119.

Gascon, C., J. R. Malcolm, J. L. Patton, M. N. F. da Silva, J. P. Bogart, S. C. Lougheed, C. A. Peres, S. Neckel, and P. T. Boag. 2000. Riverine barriers and the geographic distributions of Amazonian species. Proceedings of the National Academy of Sciences of the United States of America 97: 13672-13677.

Gehring, P. S., M. Pabijan, J. E. Randrianirina, F. Glaw, and M. Vences. 2012. The influence of riverine barriers on phylogeographic patterns of Malagasy reed frogs (Heterixalus). Molecular Phylogenetics and Evolution 64: 618-632.

Hayes, F. E. and J. N. Sewlal. 2004. The Amazon River as a dispersal barrier to passerine birds: effects of river width, habitat and taxonomy. Journal of Biogeography 31: 1809-1818.

Hothorn, T., K. Hornik, M. A. van de Wiel, and A. Zeileis. 2008. Implementing a class of permutation tests: the coin package. Journal of Statistical Software 28: 1-14.

Köhler, J., M. Jansen, A. Rodríguez, P. J. R. Kok, L. F. Toledo, M. Emmrich, F. Glaw, C. F. B. Haddad, M. O. Rödel, and M. Vences. 2017. The use of bioacoustics in anuran taxonomy: theory, terminology, methods and recommendations for best practice. Zootaxa 4251: $1-124$.

Korkmaz, S., D. Goksuluk, and G. Zararsiz. 2014. MVN: An $\mathrm{R}$ Package for assessing multivariate normality. The $R$ Journal 6: 151-163.

Liaw, A. and M. Wiener. 2002. Classification and regression by randomForest. $R$ News 2: 18-22. 
Lougheed, S. C., C. Gascon, D. A. Jones, J. P. Bogart, and P. T. Boag. 1999. Ridges and rivers: a test of competing hypotheses of Amazonian diversification using a dartpoison frog (Epipedobates femoralis). Proceedings of the Royal Society B: Biological Sciences 1431: 18291835.

Patton, J. L., M. N. F. da Silva, and J. R. Malcolm. 2000. Mammals of the Rio Juruá and the evolutionary and ecological diversification of Amazonia. Bulletin of the American Museum of Natural History 244: 1-304.

Pombal, J. P. Jr. and C. F. B. Haddad. 1992. Espécies de Phyllomedusa do grupo burmeisteri do Brasil oriental, com descrição de uma espécie nova (Amphibia, Hylidae). Revista Brasileira de Biologia 52: 217-229.

R Core Team. 2017. R: A Language and Environment for Statistical Computing (Computer software). R Foundation for Statistical Computing, Vienna, Austria. Version 3.1.2. URL: http://www.R-project.org/.

Silva-Filho, I. S. N. and F. A. Juncá. 2006. Evidence of full species status of the Neotropical leaf-frog Phyllomedusa burmeisteri bahiana (A. Lutz, 1925) (Amphibia, Anura, Hylidae). Zootaxa 1113: 51-64.

Sueur, J., T. Aubin, and C. Simonis. 2008. Seewave, a free modular tool for sound analysis and synthesis. Bioacoustics 18: 213-226.

Wallace, A. R. 1852. On the monkeys of the Amazon. Proceedings of the Zoological Society of London 20: $107-110$.

Watters, J. L., S. T. Cummings, R. L. Flanagan, and C. D. Siler. 2016. Review of morphometric measurements used in anuran species descriptions and recommendations for a standardized approach. Zootaxa 4072: 477-495.

Yuan, Z.-Y., C. Suwannapoom, F. Yan, N. A. Poyarkov Jr., S. N. Nguyen, H. Chen, S. Chomdej, R. W. Murphy, and J. Che. 2016. Red River barrier and Pleistocene climatic fluctuations shaped the genetic structure of Microhyla fissipes complex (Anura: Microhylidae) in southern China and Indochina. Current Zoology 62: 531-543.

Editor: Jaime Bertoluci 


$$
\begin{aligned}
& \text { Appendix I. Specimens examined. } \\
& (*=\text { voucher specimen of the genetic analyses by Brunes et al. 2014.) }
\end{aligned}
$$

Phyllomedusa burmeisteri: adult males of the BUR-RJ evolutionary unit: BRAZIL. RIo DE JANEIRO: Cachoeiras de Macacu: CFBH 30766-30768*; Campos dos Goytacazes: CFBH 27386-27388*, 27390*; Duque de Caxias: MNRJ 3079, 10070, 54770, 67493; Engenheiro Paulo de Frontin (Sacra Família do Tinguá): ZUEC 8089; Macaé: AAG-UFU 0530-0531, 0751; Nova Iguaçu: ZUEC 2804-2805, MNRJ 67422-67423, 67665-67669; Petrópolis: ZUEC 10917; Rio de Janeiro: MNRJ 67308 (Estrada dos Teixeiras, Jacarepaguá), MNRJ 67310 (Jacarepaguá), MNRJ 60678 (Serra do Mendanha), ZUEC 6521 (Campo Grande); Tijuca (Rio de Janeiro; type locality): MNRJ 11286, 67494 (both from estrada velha, Tijuca), 67496 (Tijuca, Guanabara); Santa Maria Madalena: CFBH 27326-27329*; São Gonçalo: MNRJ 67495; São Pedro da Aldeia: MNRJ 21730; adult females of the BUR-RJ: BRAZIL. Rio DE JANEIRo: Campos dos Goytacazes: CFBH 27389*; Iguaba Grande: MNRJ 57805; Rio de Janeiro: MNRJ 251; São Pedro da Aldeia: MNRJ 21729; adult males of the BUR evolutionary unit: BRAZIL. MinAs Gerais: Alpinópolis: AAG-UFU 0958, 4860-4862; Carangola: CFBH 27299*, 27301*; Chiador: AAG-UFU 0678; Conceição do Mato Dentro (Serra do Cipó): ZUEC 16402; Juiz de Fora: CFBH 27257*; Matutina: ZUEC 1797; São José da Barra: ZUEC 1835; Viçosa: CFBH 27579*, 27583*; Espírito SANTo: Linhares: ZUEC 3726; CFBH 18084*, CFBH 24841*; SÃo Paulo: Atibaia: AAG-UFU 0444, 0585, 0949, 1288; Campinas: AAG-UFU 1886-1888; Corumbataí: ZUEC 8518; Itatiba: AAG 0049, 0195-0196, Jundiaí: ZUEC 4538; Nazaré Paulista: CFBH 30573-30574*; Rio Claro: CFBH 14428*; Santo André (Paranapiacaba): ZUEC 4494, 6047.

Phyllomedusa bahiana (adult males): BRAZIL. BAHIA: Alagoinhas: ZUEC 19952-19960; Gandu: ZUEC 8706-8707; Ilhéus: AAG-UFU 0228-0230; Itagibá: ZUEC 3760-3761; Jequié: ZUEC 3251, 8319; Maracás: ZUEC 0976, 7590-7591; Piatã: AAG-UFU 1677-1679. 
Andrade et al.

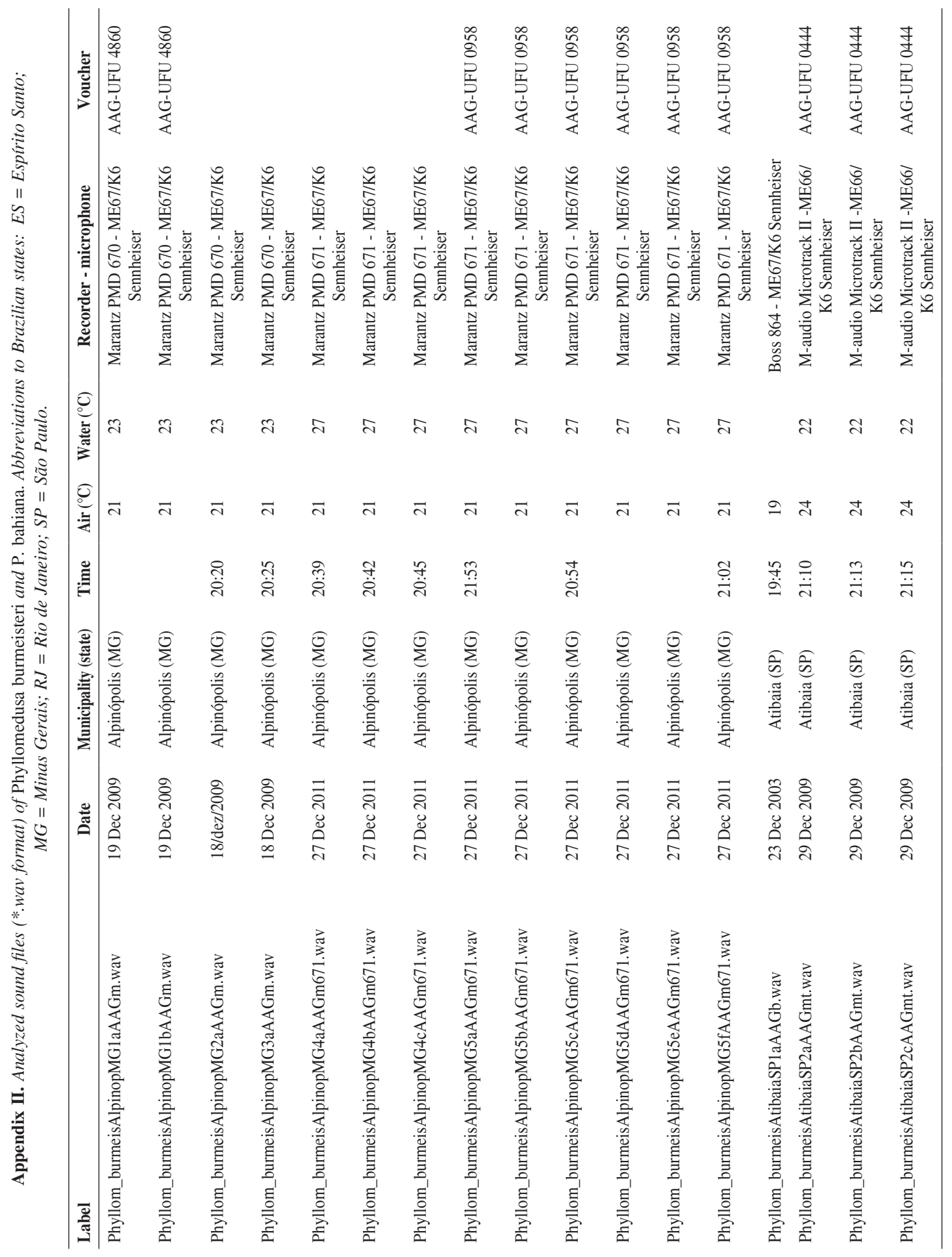




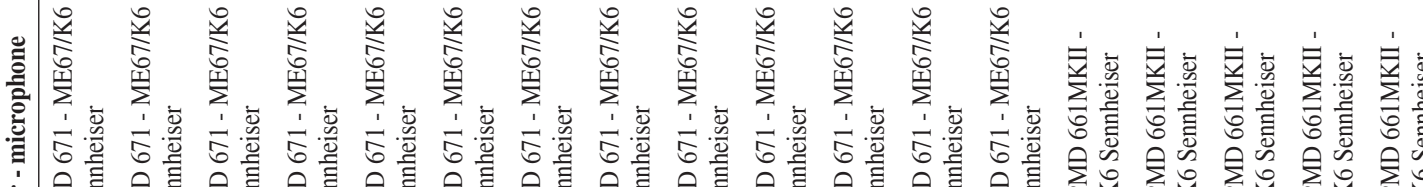

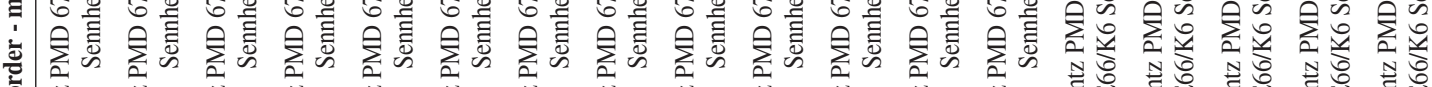

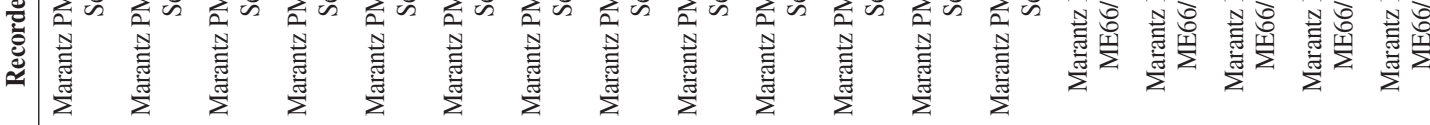
อ

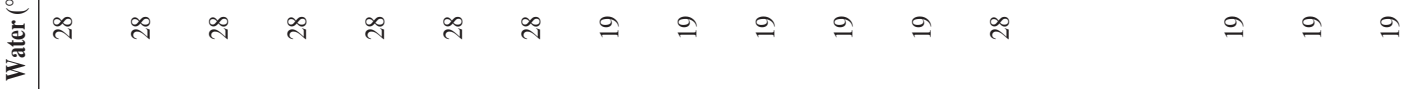

ฮี้

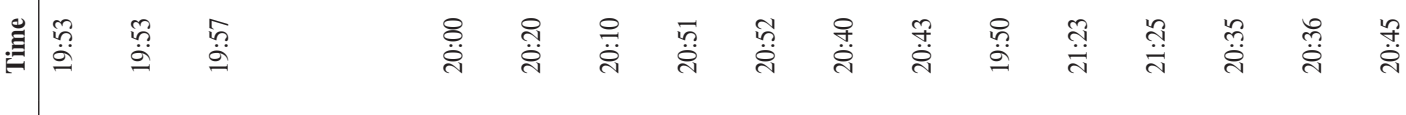

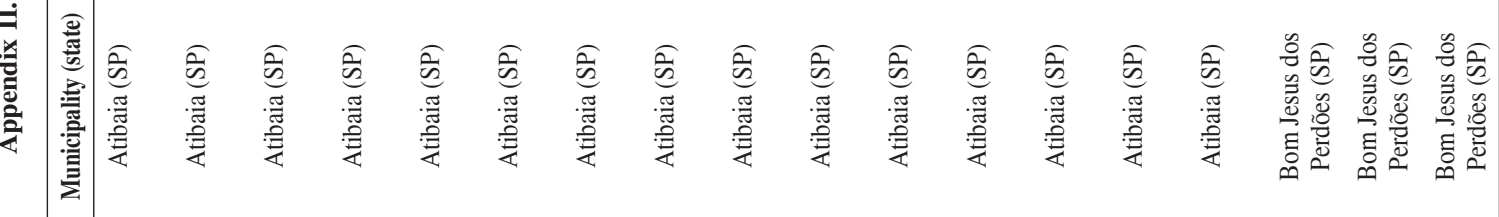

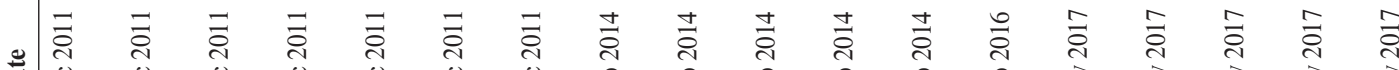

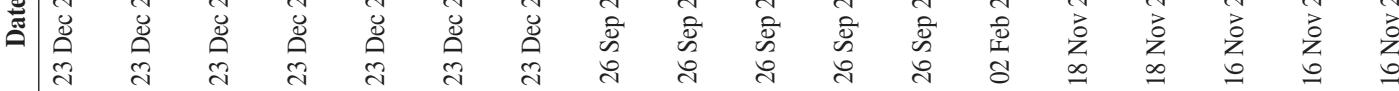

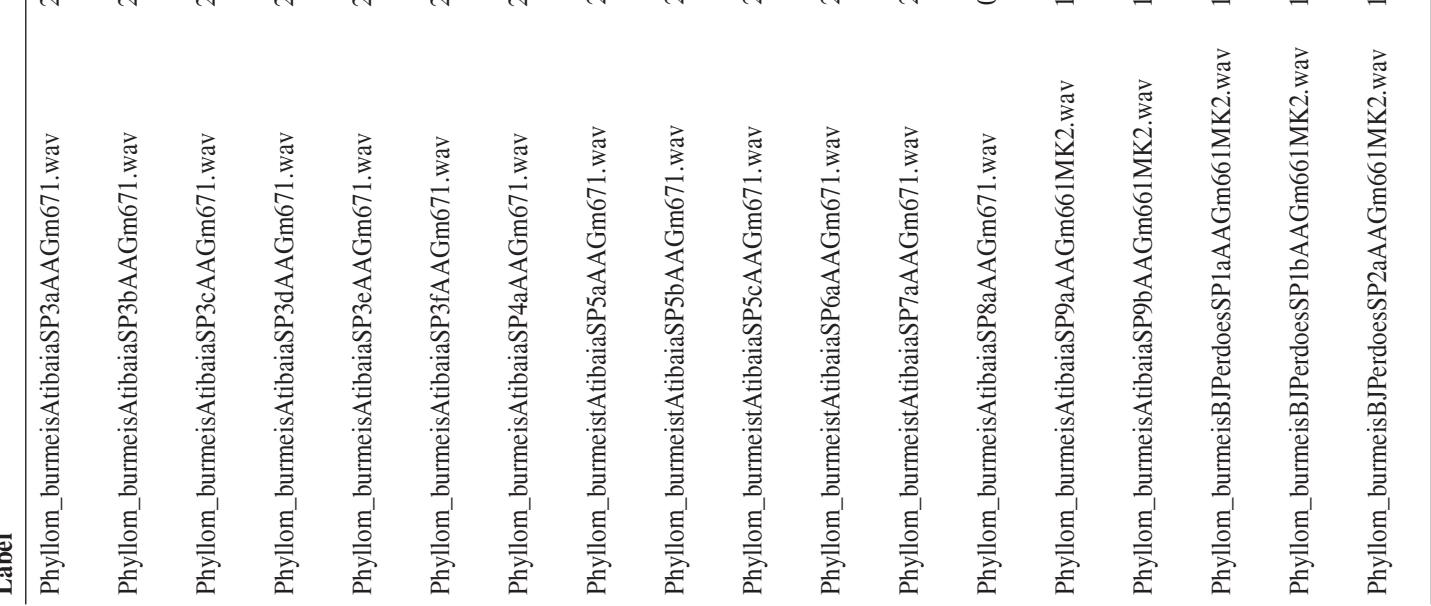


Andrade et al.

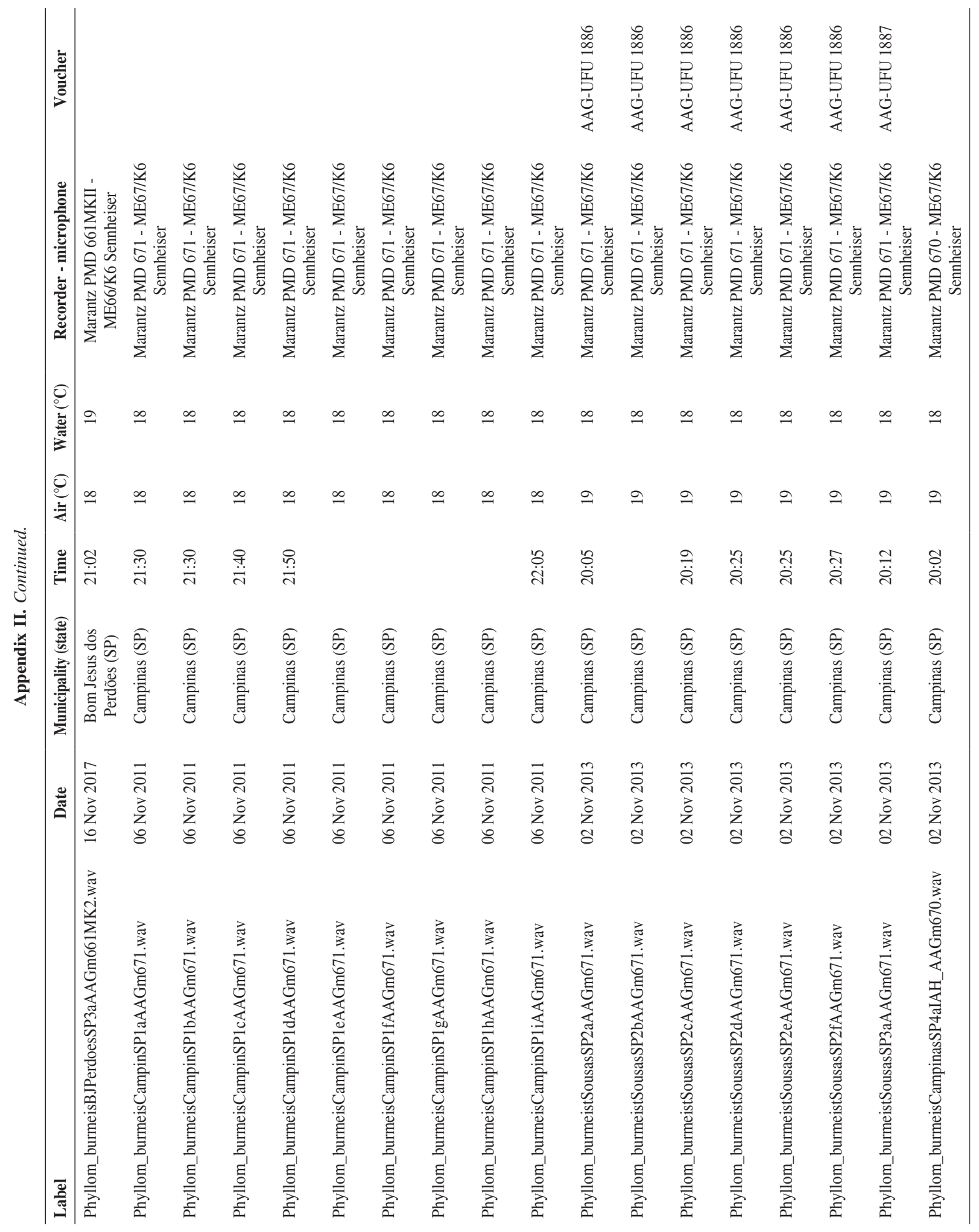




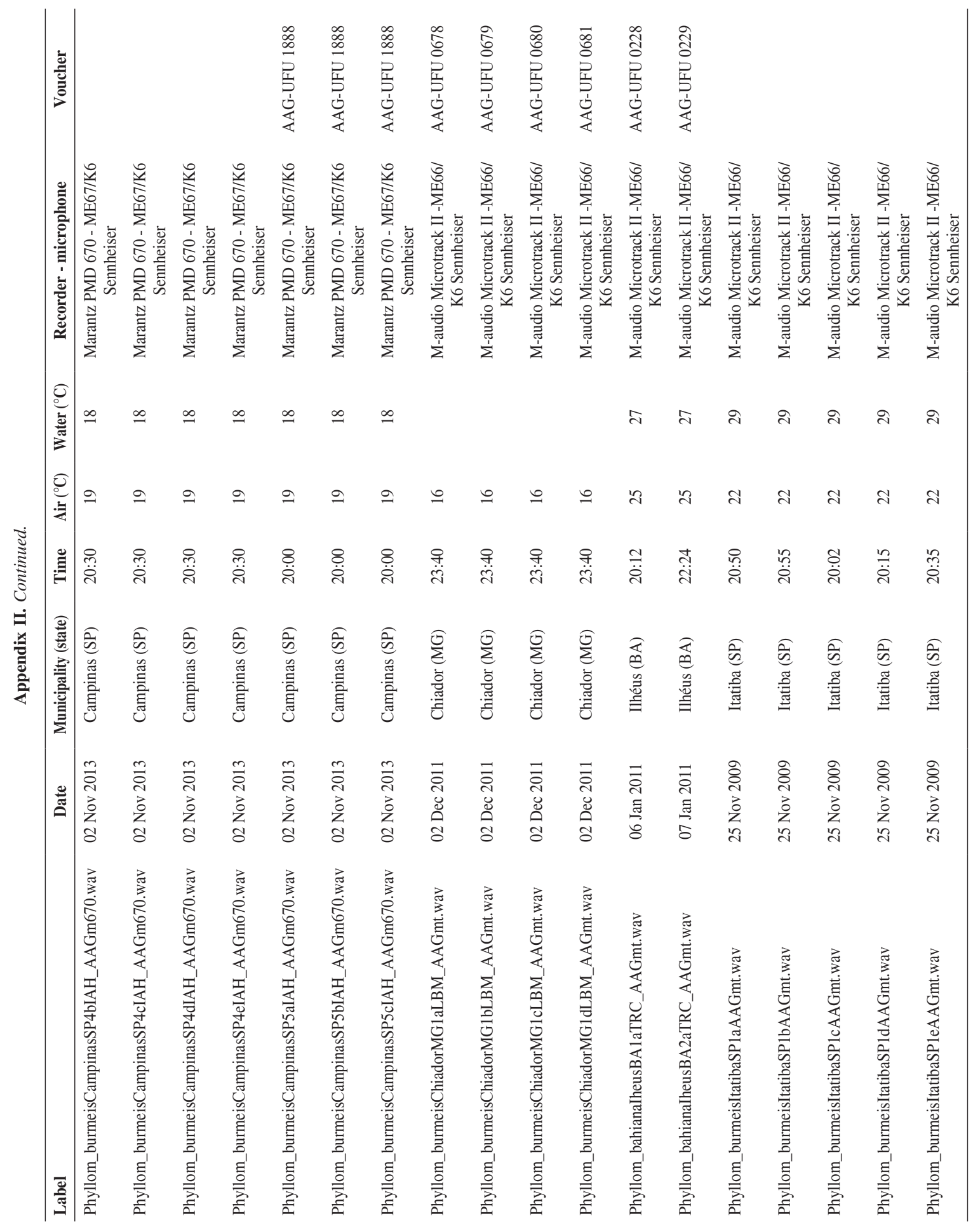




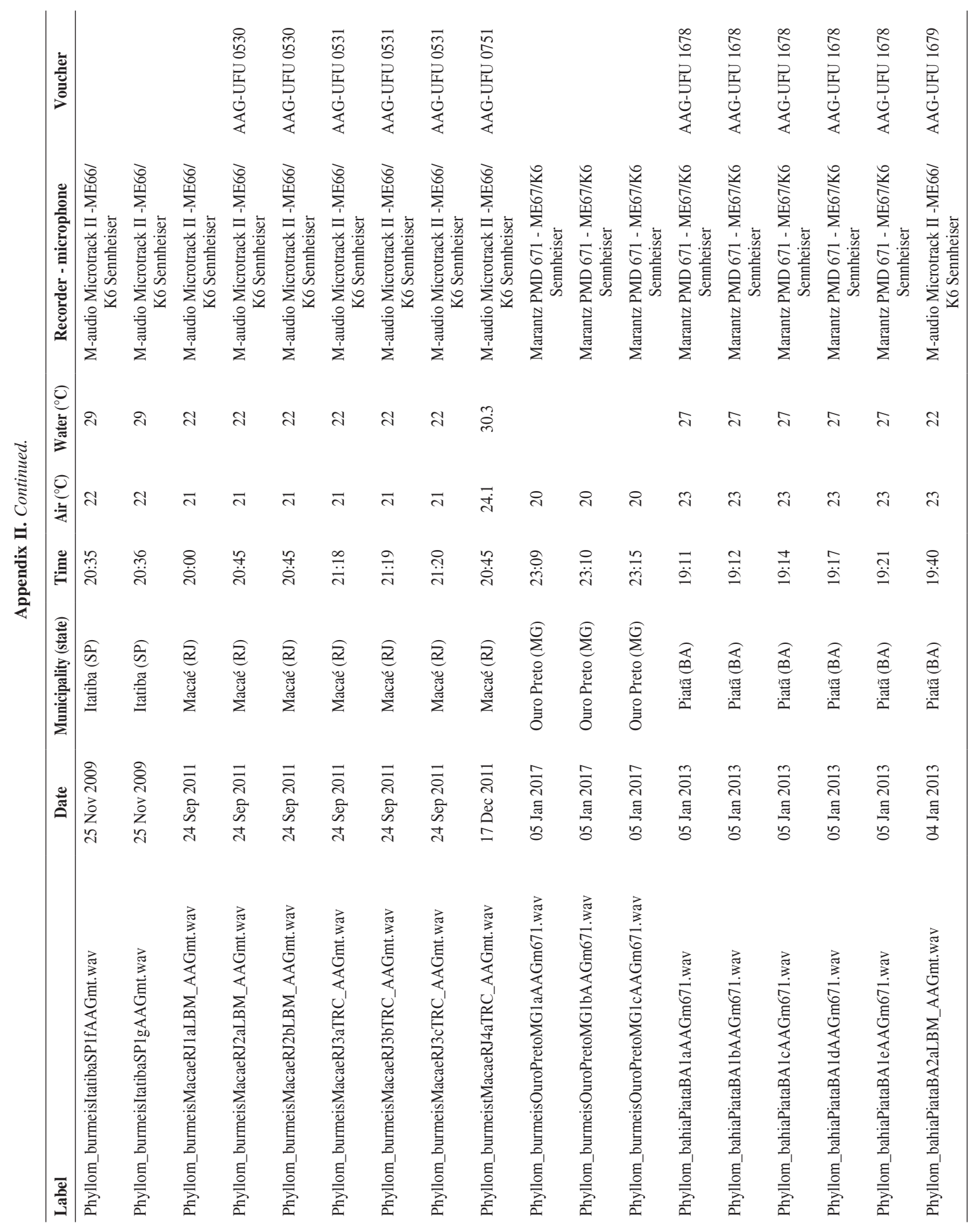




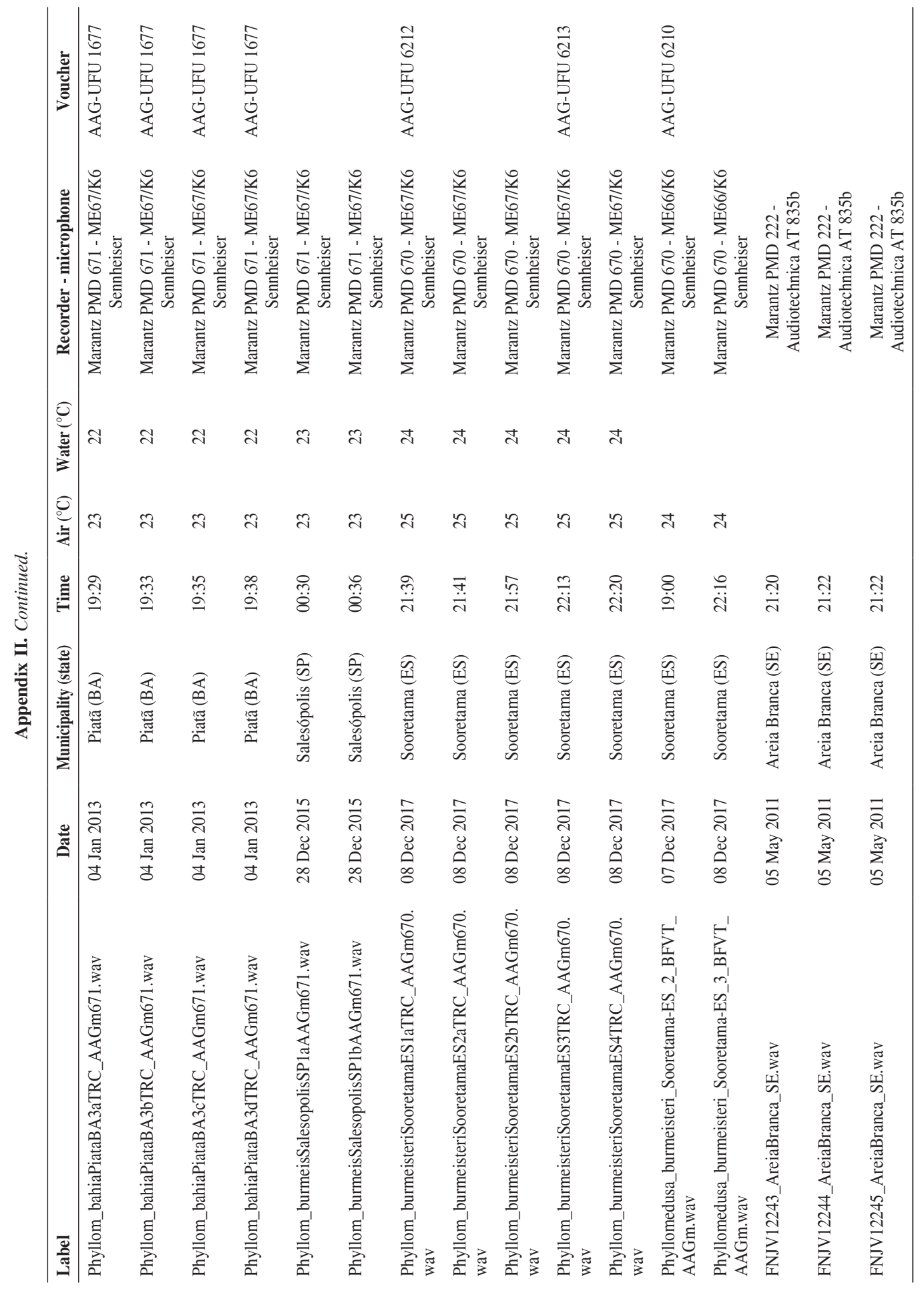

